Article

\title{
Potential of Briquetting as a Waste-Management Option for Handling Market-Generated Vegetable Waste in Port Harcourt, Nigeria
}

\author{
Olugbemiro M. Akande ${ }^{1, *}$ and Abel O. Olorunnisola ${ }^{2}$ \\ 1 Pan African University Life and Earth Sciences Institute (including Health and Agriculture), \\ University of Ibadan, Ibadan 200284, Nigeria \\ 2 Department of Wood Products Engineering, University of Ibadan, Ibadan 200284, Nigeria; \\ abelolorunnisola@yahoo.com \\ * Correspondence: akandeolumajo@yahoo.com; Tel.: +234-803-045-4620
}

Received: 8 March 2018; Accepted: 27 March 2018; Published: 28 March 2018

\begin{abstract}
The conversion of biomass to high-density briquettes is a potential solution to solid waste problems as well as to a high dependence on fuel wood in developing countries. In this study, the potential of converting vegetable waste to briquettes using waste paper as a binder was investigated. A sample size of 30 respondents was interviewed using a self-administered questionnaire at the D-line fruit and vegetable market in Port Harcourt, Nigeria. Carrot and cabbage leaves were selected for briquetting based on their availability and heating value. This waste was sun-dried, pulverized, torrefied and fermented. Briquettes were produced with a manual briquette press after the processed vegetable waste was mixed with waste paper in four paper:waste ratios, i.e., 10:90, 15:85, 20:80 and 25:75. The moisture content, densities and cooking efficiency of the briquettes were determined using the oven-drying method, the water-displacement method, and the water-boiling test, respectively. There was no observed trend in moisture content values of the briquettes, which varied significantly between $3.0 \%$ and $8.5 \%$. There was no significant variation in the densities, which ranged from $0.79 \mathrm{~g} / \mathrm{cm}^{3}$ to $0.96 \mathrm{~g} / \mathrm{cm}^{3}$ for all the briquette types. A degree of compaction above $300 \%$ was achieved for all the briquette types. Water-boiling test results revealed that 10:90 paper:sun-dried cabbage briquettes had the highest ignitability of $0.32 \mathrm{~min}$. Torrefied carrot briquettes with $25 \%$ paper had the least boiling time and the highest burning rates of $9.21 \mathrm{~min}$ and $4.89 \mathrm{~g} / \mathrm{min}$, respectively. It was concluded that cabbage and carrot waste can best be converted into good-quality briquettes after torrefaction.
\end{abstract}

Keywords: briquetting; vegetable waste; solid-waste management; biomass

\section{Introduction}

The management of municipal solid waste poses various challenges to many countries of the world at varying intensities. The primary difference between waste materials generated in developing nations and those generated in industrialized countries is the higher organic content characteristic of the former. This further aggravates the already existing challenge due to the bulky nature of organic waste and the unpleasant accompaniments of putrefaction [1]. Nevertheless, embedded in this challenge is an opportunity which represents the direction in which the world is heading in the "energy cycle". In recent decades, there has been a strong worldwide interest in the development of technologies that exploit renewable energy sources (green energy), both for its environmental and economic benefits [2]. According to Jekayinfa and Scholz [3] a country like Nigeria has abundant supplies of biomass resources, particularly in the form of agro-forestry residues and municipal solid waste which have the potential for energy generation. 
Furthermore, deforestation partly resulting from the overarching dependence on forests for fuel wood and the burning of fossil fuels are two major contributors to anthropogenic climate change [4]. Adegbulugbe [5] predicted that by 2030 the demand for fuel wood is expected to have increased to about $213.4 \times 10^{3}$ metric tonnes, while the supply would have decreased to about $28.4 \times 10^{3}$ metric tonnes. This imbalance in fuel wood demand/supply has been reported in the National Energy Policy of Nigeria. On the national scale, increasing fuel wood consumption contributes to deforestation, with consequent desertification and soil erosion [6]. The decreasing availability of fuel wood engendered by large-scale deforestation, coupled with increasing prices of kerosene and cooking gas in Nigeria, emphasizes the need for alternative sources of energy which should be renewable and accessible to the poor [7]. Therefore, relying on biomass for the production of briquettes is a potential solution to solid waste problems in developing countries as well as the high dependence on fuel wood.

The conversion of biomass to energy can be achieved through various technologies such as direct/stove, biomass briquette and boiler combustion; thermochemical conversion (which includes gasification, pyrolysis and liquefaction); and biochemical conversion (anaerobic fermentation biogas, bioethanol and biodiesel) [8-12]. The major limitations of direct combustion are the low heating efficiency and difficulty in handling, storage and transportation resulting from the low bulk density and high moisture content of the biomass materials $[9,13]$. One solution to these problems is to increase the density of the biomass by conversion to briquettes [14]. Despite outstanding advantages (such as higher conversion rate and easy industrialization) of the more recent biomass energy technologies, there are certain limitations to their utilization. For example, biomass gasification requires a gasifier and the reaction process is very complex [9]. According to Veringa [10], interest in the liquefaction process is reduced by the high cost of pressure reactors. Although biomass briquetting tends to have relatively high operating costs [9], the combustion efficiency is greatly improved through torrefaction. Furthermore, sun-drying the raw materials and the briquettes after production prevent additional energy expenditure. Also, briquetting requires less expertise compared to more recent conversion techniques.

A number of studies point to the fact that feed stocks of municipal solid waste (MSW) origin have potential for briquetting. Omari et al. [15] characterized and evaluated MSW in Arusha, Tanzania and determined the amount of energy that could be recovered from the waste. Raju et al. [16] produced and tested briquettes from almond leaves, sawdust and cocoa-peat based on their availability and ability to bond together when compressed. Srivastava et al. [17] converted vegetable market waste to briquettes without pre-treatment and without using any external binders. Torrefaction combined with briquetting yields a highly energy-dense fuel carrier of 20-25 GJ/tonne [18] and this has been confirmed by Felfi et al. [19] in their study of wood briquette torrefaction. The aim of this study was to examine the current waste-management strategies for fruits and vegetables at D-line market in Port Harcourt, Nigeria and suitable pre-treatment methods for briquetting selected wastes that were more abundant and had relatively high energy contents.

\section{Materials and Methods}

\subsection{Study Area}

The study area was the D-line fruit and vegetable market in Port Harcourt, Rivers State, Nigeria. Port Harcourt is the capital and largest city of Rivers State, Nigeria. It lies on latitude $40^{\circ} 49^{\prime} \mathrm{N}$ and longitude $70^{\circ} 21^{\prime}$ E. The population of Port Harcourt urban area is said to have increased to an estimated 1,865,000 inhabitants in 2016, from 1,382,592 as of 2006 [20]. Annual municipal solid waste generation for Port Harcourt was estimated to be 265,129 MT and 352,853 MT for the years 1990 and 2000, respectively [21], while per capita generation ranges between 1.11 and $1.25 \mathrm{~kg} /$ cap/day [22-24]. About $69 \%$ of the waste generated in Port Harcourt is organic in composition [24] as shown in Figure 1. 


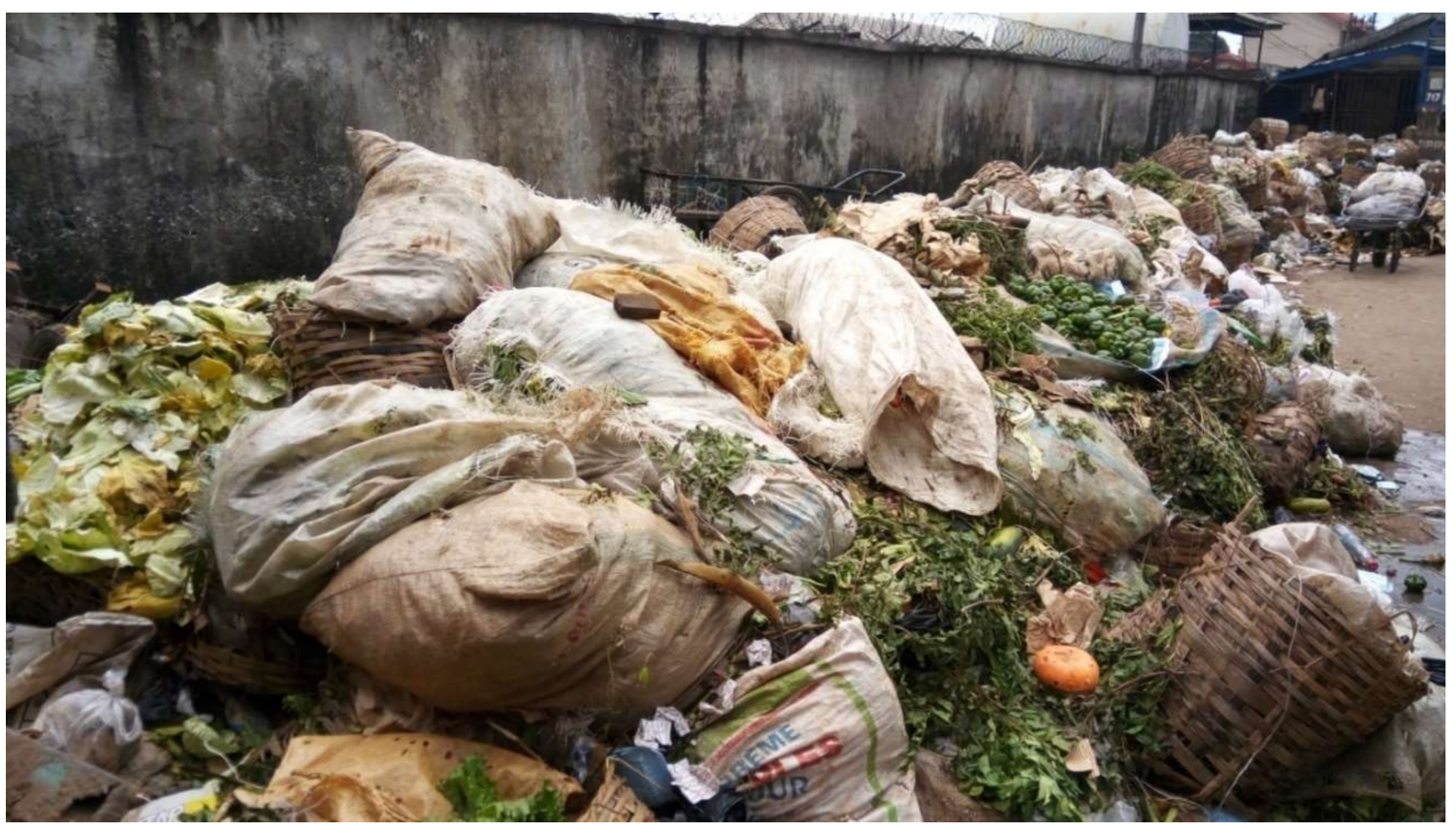

Figure 1. Waste heap at the D-line fruit and vegetable market, Port Harcourt, Nigeria.

\subsection{Data-Collection Methods}

Primary data was obtained from 30 randomly selected respondents through a self-administered questionnaire to determine the types of fruit and vegetable waste found in the market and the strategies adopted in the management of fruit and vegetable waste at the market. Samples of vegetable waste were also collected for conversion to briquettes. Secondary data sources such as journal articles were consulted to determine the heating values of various biomass materials for briquetting.

\subsection{Briquette Preparation}

The waste for briquetting was selected using a Likert scale based on respondents' perception of which wastes were highly available, moderately available, or poorly available at the market. This selection was based on: (i) the heating value of the materials as tabulated in literature-for example, residues with relatively high energy content were selected; and (ii) the level of availability of the waste-for example, the residues that met the aforementioned condition and were readily available were given preference.

The waste materials selected were cabbage and carrot leaves. The vegetable waste was collected and sun-dried for 10 days. The dried biomass was manually pulverized. A portion of the vegetable waste was used as is, another portion was torrefied by roasting in a container on a kerosene stove for about $2 \mathrm{~h}$, while the third portion was left to ferment for 5 days. Each of the portions was mixed with waste paper which had been turned to pulp to serve as a binder in the following paper:waste ratios: 10:90, 15:85, 20:80, and 25:75. The paper and vegetable waste materials were thoroughly mixed and then hand fed into the manual briquetting press and compacted at an average pressure of $3.5 \mathrm{MPa}$ using a hydraulic jack equipped with a pressure gauge. The briquettes were allowed to dry for about 2 weeks.

\subsection{Moisture Content Determination}

The moisture content of the vegetable waste was determined by measuring their fresh weight and dry weight. The percentage difference between these two weights gave an estimate of the moisture content of the waste materials. The moisture content (dry basis) of the briquettes was determined 
using the oven-dry method as carried out by Onukak et al. [25] using three samples of briquettes from each treatment.

Table 1. Interview respondents' age-gender cross tabulation.

\begin{tabular}{ccc}
\hline Age Group & Male $\%$ & Female $\%$ \\
\hline 20 and below & $15.4 \%$ & $23.6 \%$ \\
$21-30$ & $38.4 \%$ & $17.6 \%$ \\
$31-40$ & $23.1 \%$ & $29.4 \%$ \\
$41-50$ & $15.4 \%$ & $29.4 \%$ \\
Over 50 & $7.7 \%$ & $0 \%$ \\
Total & $100 \%$ & $100 \%$ \\
\hline
\end{tabular}

\subsection{Density Determination}

The bulk density of the vegetable waste was determined by weighing the materials in an open top rectangular carton box of $2338.125 \mathrm{~cm}^{3}$ volume. True densities of the biomass and briquettes (dry basis) were determined using the mass and volume relationship [26]. The degree of compaction of the briquetted materials was calculated as percent increase in true density over bulk density of ground residues, as in Srivastava et al. [17].

\subsection{Water-Boiling Test}

This test was carried out to compare the cooking efficiency of the various briquette types. It involved boiling an equal volume $\left(100 \mathrm{~cm}^{3}\right)$ of water with a fixed mass $(100 \mathrm{~g})$ of the various briquette types as reported by Onuegbu et al. [27], using a typical local charcoal stove. During this test, the smoke evolution level was observed and other properties including ignition time, boiling time and burning rate of the briquettes were measured, as reported by Onukak et al. [25] and Onuegbu et al. [27].

\subsection{Statistical Analysis}

The statistical analysis was performed using the Statistical Package for Social Sciences (IBM SPSS Statistics 20) after a coding questionnaire. Simple descriptive statistics such as mean, standard deviation and graphs were obtained. Moisture content and density data were subjected to one-way analysis of variance (ANOVA) in the same software. Homogeneity of variance assumption was tested using Levene's test. The Games-Howell testwas used when the homogeneity of variance assumption was violated.

\section{Results}

\subsection{Respondents' Demographics}

Out of the 30 respondents interviewed, $43 \%$ (13) were males while $57 \%$ (17) were females (Table 1 ). On the basis of age group, $38 \%$ of the male respondents were between 21 and 30 years old, while $29 \%$ of the female respondents were 31 and 40 years (Table 1).

\subsection{Fruit and Vegetable Waste Availability and Management Methods}

As shown in Figure 2, cabbage waste ranked the highest with a count of 49, followed by lettuce waste (40), green bean waste (34) and carrot (26). The least available waste materials were those of maize, pear and banana (1). The interviewswith respondents revealed that a lot of vegetable waste was generated at the market and this was poorly managed beyond the point of storage. The process of solid waste management at the market typically included storage, collection, and final disposal. The sellers swept and gathered their refuse into nylons or sacks and took them to the section of the market designated for temporary storage of the waste in heaps. This usually continued, sometimes for 
weeks due to delayed collection, leading to decay of the waste, producing an offensive odour around that section of the market.

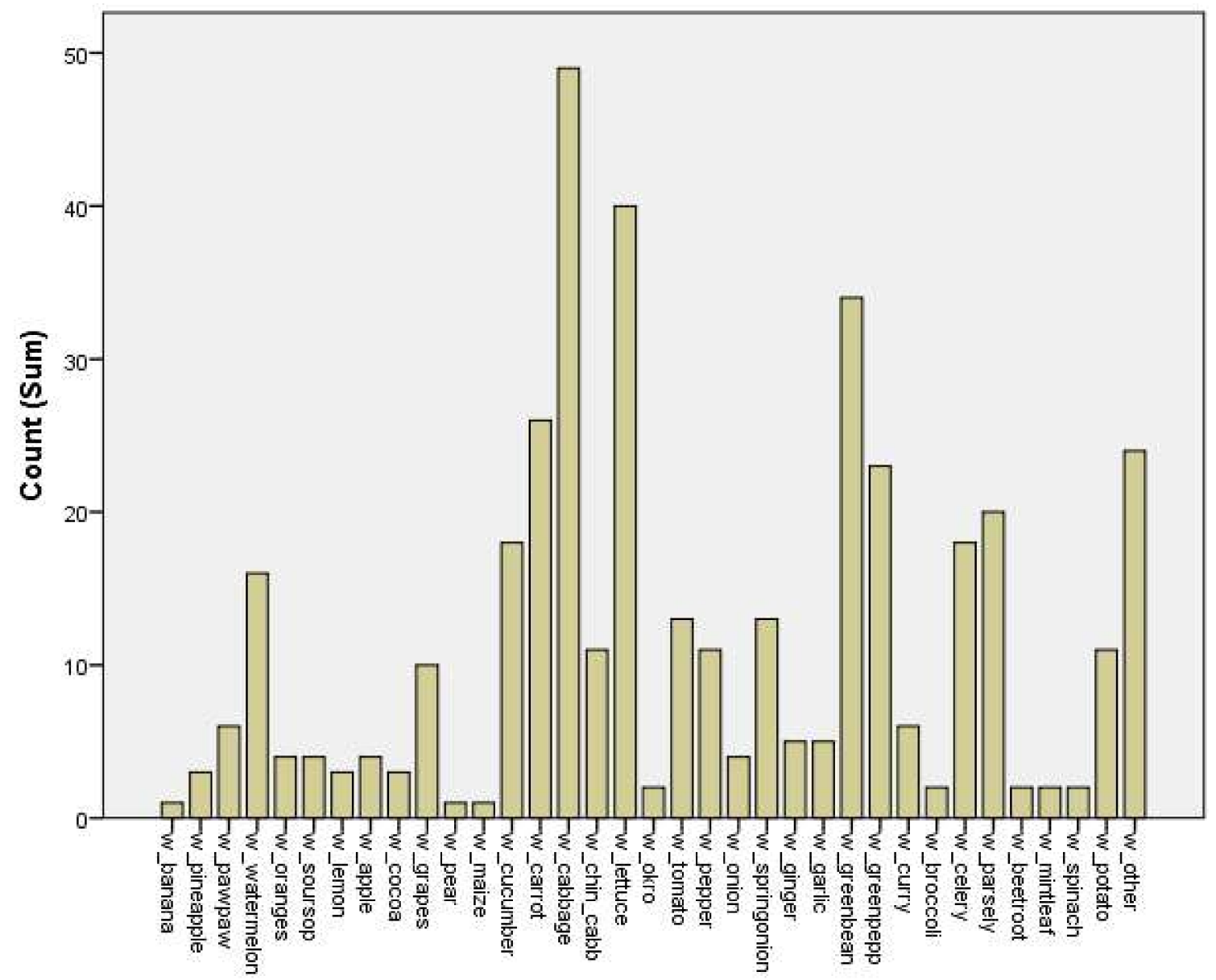

Figure 2. Availability of waste at D-line market.

Crop, rabbit and snail farmers were involved in the collection of the vegetable wastes. While the crop farmers converted the waste to compost, the rabbit and snail farmers used them as animal feedin some cases.Rather than collecting these materials from the waste themselves, the farmers paid the sellers at the market to store waste separately. However, these respondents reported that the farmers were only able to utilize a very small proportion of the waste, as a huge pile of waste was still left to decay at the storage point.

The relatively large leftover matter (not quantified in this study) was handled by waste collectors for disposal; $46.7 \%$ of the respondents stated that collection was done twice a week (Wednesdays and Saturdays), but the remaining 53.3\% stated that this was not the case as the waste is allowed to rot and constitutesan environmental nuisance. It was also observed during field visits that while collection was done one Wednesday, there was no collection on the next Wednesday, indicating some level of inconsistency. After the waste was collected, it was disposed of at dumpsites whose locations were unknown to the respondents.

\subsection{Energy Needs, Sources and Estimated Cost}

Information on the domestic and business energy needs of the respondents was also obtained (Figure 3a). All (100\%) respondents indicated that they required energy for cooking, $93.3 \%$ of respondents needed energy for lighting, while $86.6 \%$ needed energy for heating. 


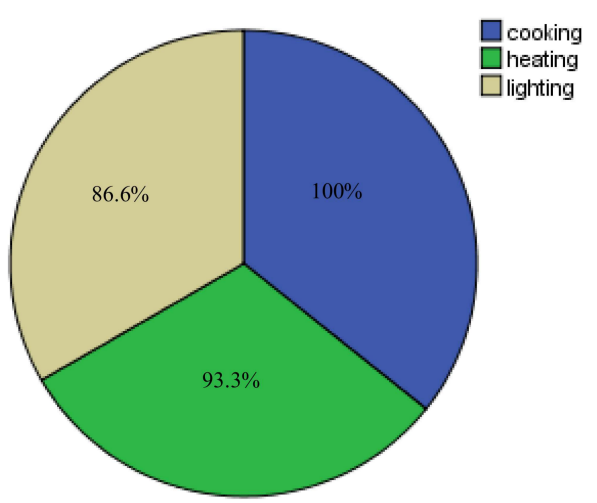

(a)

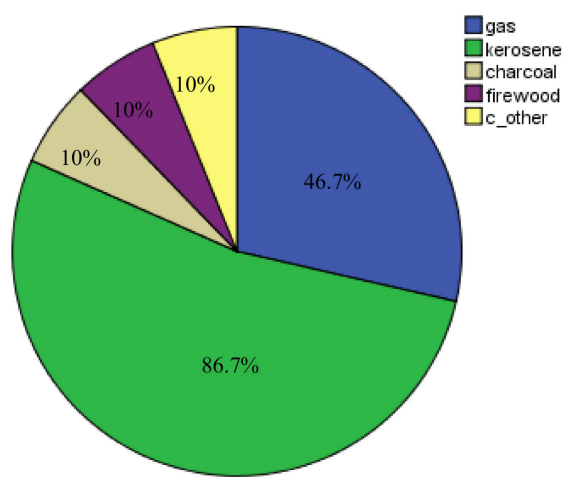

(b)

Figure 3. Distribution of energy (a) needs and (b) sources.

As shown in Figure 3b, a majority (87\%) of the respondents made use of kerosene while about half (47\%) were making use of liquefied petroleum gas (LPG). On the other hand, charcoal, firewood and electricity ranked the least $(10 \%$ each). About $67 \%$ of the respondents utilized only one source of energy (kerosene or LPG) while about 23\% used a combination of kerosene and LPG. As shown in Table 2, 36.7\% of respondents spent between $\mathrm{N} 1000$ and $\$ 4999$ on energy for cooking. Also, 36.7\% of the respondents spent between $\$ 5000$ and $\$ 9999$. In other words, more than $70 \%$ of the respondents spent less than $\mathrm{N} 10,000$ on energy for cooking in a month.

Table 2. Monthly expenditure on energy.

\begin{tabular}{cccc}
\hline Cost (\$) & Frequency & Percent & Cumulative Percent \\
\hline 1000-4999 & 11 & 36.7 & 36.7 \\
$5000-9999$ & 11 & 36.7 & 73.3 \\
10,000-14,999 & 3 & 10.0 & 83.3 \\
15,000-19,999 & 4 & 13.3 & 96.7 \\
Missing value & 1 & 3.3 & 100.0 \\
Total & 30 & 100.0 \\
\hline Note: Missing value means the respondent did not supply this information.
\end{tabular}

\subsection{Selection of Waste Materials for Briquetting}

None of the respondents at the market had heard of briquetting. Based on availability and heating value, cabbage and carrot leaf waste materials were selected for briquette production. In addition, waste paper was selected for use as a binder due to its availability and relatively high heating value. Table 3 provides a summary of the summed ranks of the most abundant wastes from the survey, with their energy content (in Kilojoules per $100 \mathrm{~g}$ ) and ash content (in g per $100 \mathrm{~g}$ ).

Table 3. Selection criteria for residues.

\begin{tabular}{ccccc}
\hline Residue & $\begin{array}{c}\text { Availability } \\
\text { (Summed Rank) }\end{array}$ & $\begin{array}{c}\text { Energy Content } \\
\mathbf{( k J / 1 0 0 ~ g ) ~}\end{array}$ & $\begin{array}{c}\text { Ash Content } \\
\mathbf{( g / 1 0 0 ~ g )}\end{array}$ & $\begin{array}{c}\text { Observed } \\
\text { Availability }\end{array}$ \\
\hline Cabbage & 49 & 126 & 0.81 & Abundant \\
Lettuce & 40 & 91 & 1.11 & Scarce \\
Green beans & 34 & 102 & 1.05 & Scarce \\
Carrot leaves & 26 & 322 & 1.2 & Abundant \\
\hline
\end{tabular}

Energy and ash content are adapted from Longvah et al. [28], Gopalan et al. [29] and Islam et al. [30].

\subsection{Effects of Pre-Treatment on Briquetting}

The briquettes produced with torrefied waste materials were more compact and definite in shape than those formed from sun-dried residues. The carrot leaves could not be adequately briquetted until 
after fermentation for a period of 5 days. After fermentation they became more compact than the briquettes made from the sun-dried cabbage leaves which were not fermented. Ease of briquetting was observed to reduce with increase in the proportion of paper used as binder for all the feed stock types (torrefied, sun-dried and sun-dried fermented). Cracks were observed on the walls of briquettes with $25 \%$ paper as they attained dryness (Figure 4 ).

\subsection{Moisture Content and Densities of Briquettes}

The moisture content of the dry loose vegetable waste materials were $48.5 \%$ and $84.9 \%$ for carrot leaves and cabbages, respectively. The moisture content of the briquettes ranged from $3.03 \%$ to $8.47 \%$, as shown in Table 4. There was a significant difference among the percentage moisture content of the 16 briquette types, $F(15,32)=4.34$ ( $F$ values at degrees of freedom between and within groups), $p<0.001$ ( $p$ significant at values less than 0.5 ). There was no discernable pattern in percentage moisture content variation either due to torrefaction or increasing the ratio of paper in the mixture.

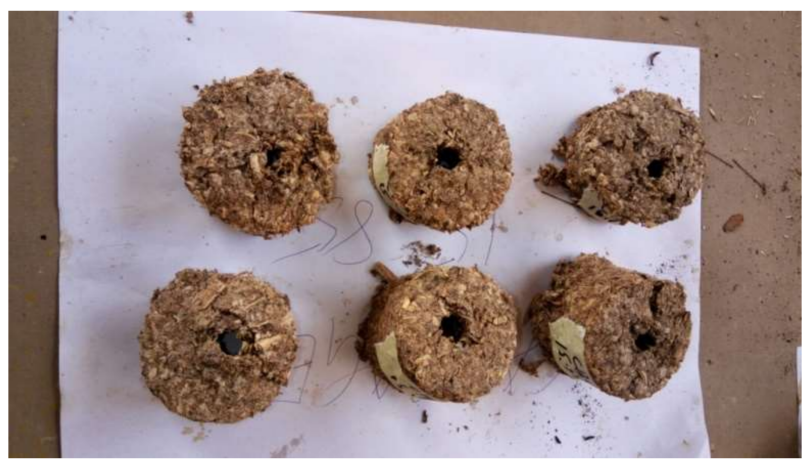

Figure 4. Samples of briquettes produced.

The bulk density of the loose carrot leaves $\left(0.228 \mathrm{~g} / \mathrm{cm}^{3}\right)$ was slightly higher than that of the cabbage leaves $\left(0.224 \mathrm{~g} / \mathrm{cm}^{3}\right)$. The densities of briquettes ranged from $0.79 \mathrm{~g} / \mathrm{cm}^{3}$ to $0.96 \mathrm{~g} / \mathrm{cm}^{3}$. There was no significant difference among the densities of the 16 briquette types, $F(15,64)=1.14, p=0.338$. There was also no observable trend in variation of densities with an increase in the amount of paper used as binder for both cabbage and carrot briquettes. Degree of densification ranged from $343 \%$ to $436 \%$ for all briquette types, the highest being 15:85 paper:sun-dried cabbage briquettes and the lowest being 15:85 paper:sun-dried carrot briquettes.

Table 4. Moisture content and densities of the briquettes.

\begin{tabular}{|c|c|c|c|c|}
\hline Briquette Code & Briquette Type & MC (\%) & Density $\left(\mathrm{g} / \mathrm{cm}^{3}\right)$ & Degree of Compaction (\%) \\
\hline BO10 & 10:90 paper: sun-dried cabbage & $8.37 \pm 1.91$ & $0.86 \pm 0.13$ & 391 \\
\hline BO15 & 15:85 paper: sun-dried cabbage & $8.47 \pm 0.40$ & $0.96 \pm 0.16$ & 436 \\
\hline $\mathrm{BO} 20$ & 20:80 paper: sun-dried cabbage & $4.61 \pm 1.42$ & $0.85 \pm 0.04$ & 386 \\
\hline $\mathrm{BO} 25$ & $25: 75$ paper: sun-dried cabbage & $4.71 \pm 1.67$ & $0.83 \pm 0.06$ & 377 \\
\hline TBO10 & 10:90 paper: torrefied cabbage & $3.03 \pm 1.40$ & $0.84 \pm 0.04$ & 382 \\
\hline TBO15 & 15:85 paper: torrefied cabbage & $3.25 \pm 0.88$ & $0.79 \pm 0.06$ & 359 \\
\hline TBO20 & 20:80 paper: torrefied cabbage & $3.14 \pm 0.51$ & $0.81 \pm 0.06$ & 368 \\
\hline TBO25 & 25:75 paper: torrefied cabbage & $3.74 \pm 1.36$ & $0.89 \pm 0.09$ & 405 \\
\hline DC10 & 10:90 paper: sun-dried carrot & $6.13 \pm 0.21$ & $0.79 \pm 0.13$ & 343 \\
\hline DC15 & 15:85 paper: sun-dried carrot & $5.47 \pm 0.36$ & $0.90 \pm 0.13$ & 391 \\
\hline DC20 & 20:80 paper: sun-dried carrot & $7.92 \pm 4.73$ & $0.87 \pm 0.13$ & 378 \\
\hline DC25 & 25:75 paper: sun-dried carrot & $3.53 \pm 0.07$ & $0.87 \pm 0.06$ & 378 \\
\hline TDC10 & 10:90 paper: torrefied carrot & $3.16 \pm 0.06$ & $0.87 \pm 0.06$ & 378 \\
\hline TDC15 & 15:85 paper: torrefied carrot & $4.11 \pm 0.10$ & $0.90 \pm 0.07$ & 391 \\
\hline TDC20 & 20:80 paper: torrefied carrot & $5.47 \pm 2.16$ & $0.89 \pm 0.09$ & 387 \\
\hline TDC25 & 25:75 paper: torrefied carrot & $3.20 \pm 0.06$ & $0.86 \pm 0.13$ & 391 \\
\hline
\end{tabular}




\subsection{Water-Boiling Test}

As the briquettes burned, it was observed that while those made from sun-dried residues emitted much smoke, those made from torrefied residues emitted very little smoke. As shown in Table 5, the ignition time ranged from $0.32 \mathrm{~min}$ to $4.12 \mathrm{~min}$. An increase in ignitability with increase in paper concentration was observed in the cabbage briquettes (Figure $5 a, b$ ). The reverse was the case for the carrot briquettes (Figure 6a,b). Boiling time ranged from $9.21 \mathrm{~min}$ to $32.32 \mathrm{~min}$, while the burning rate was between $1.75 \mathrm{~g} / \mathrm{min}$ and $4.89 \mathrm{~g} / \mathrm{min}$. The burning rates for all briquette types increased with the increase in percentage of paper used as binder (Figures 5 and 6).

Table 5. Results of water-boiling test of briquettes.

\begin{tabular}{|c|c|c|c|c|c|}
\hline Briquette Code & Briquette Type & $\begin{array}{l}\text { Mass of Briquette } \\
\text { Consumed (g) }\end{array}$ & $\begin{array}{l}\text { Ignition Time } \\
\text { (min) }\end{array}$ & $\begin{array}{l}\text { Water Boiling } \\
\text { Time (min) }\end{array}$ & $\begin{array}{c}\text { Burning Rate } \\
(\mathrm{g} / \mathrm{min})\end{array}$ \\
\hline BO10 & 10:90 paper: sun-dried cabbage & 61 & 0.32 & 32.32 & 1.89 \\
\hline BO15 & 15:85 paper: sun-dried cabbage & 66 & 0.45 & 25.03 & 2.64 \\
\hline $\mathrm{BO} 25$ & 25:75 paper: sun-dried cabbage & 68 & 1.43 & 14.37 & 4.73 \\
\hline TBO10 & 10:90 paper: torrefied cabbage & 36 & 1.19 & 19.35 & 1.86 \\
\hline TBO15 & 15:85 paper: torrefied cabbage & 41 & 1.41 & 16.30 & 2.52 \\
\hline DC10 & 10:90 paper: sundried carrot & 78 & 4.12 & 26.52 & 2.94 \\
\hline DC15 & 15:85 paper: sundried carrot & 65 & 3.00 & 19.34 & 3.36 \\
\hline DC20 & 20:80 paper: sundried carrot & 62 & 1.40 & 19.11 & 3.24 \\
\hline DC25 & 25:75 paper: sundried carrot & 73 & 1.32 & 21.47 & 3.40 \\
\hline TDC10 & 10:90 paper: torrefied carrot & 39 & 2.44 & 22.25 & 1.75 \\
\hline TDC15 & 15:85 paper: torrefied carrot & 43 & 1.35 & 14.24 & 3.02 \\
\hline
\end{tabular}

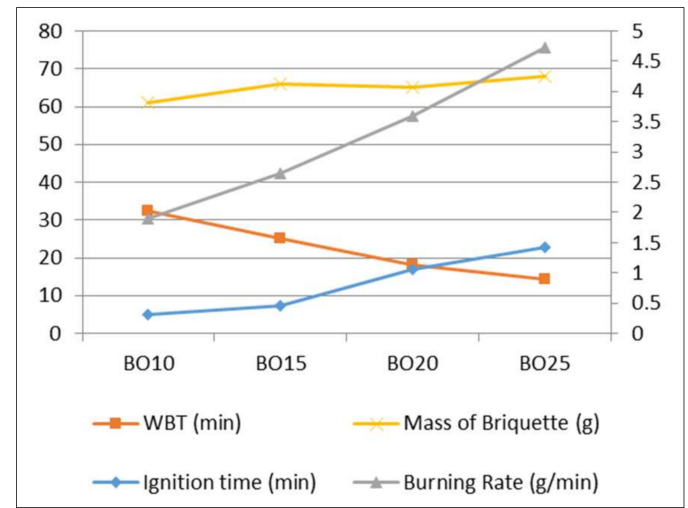

(a)

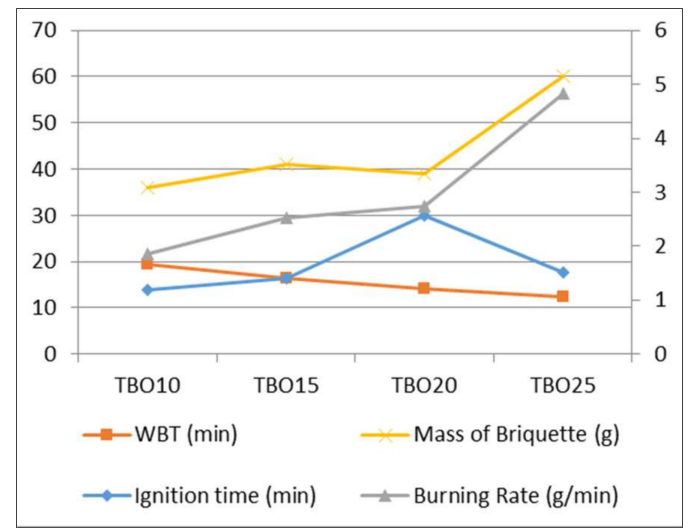

(b)

Figure 5. Thermal characteristics of (a) sun-dried and (b) torrefied cabbage briquettes. 


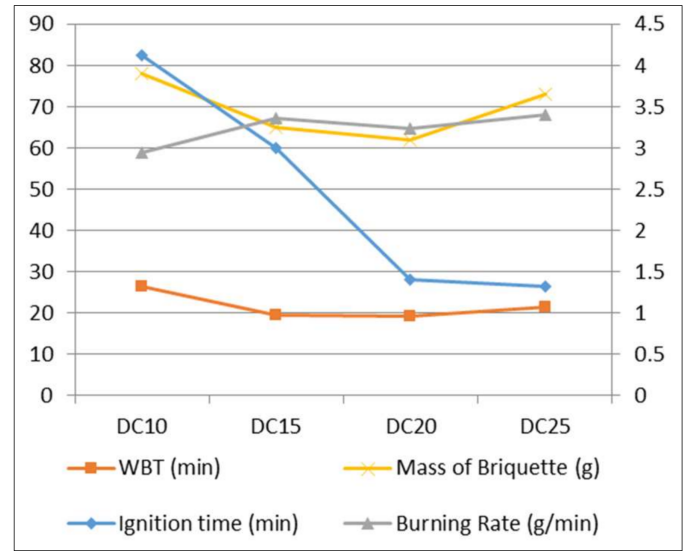

(a)

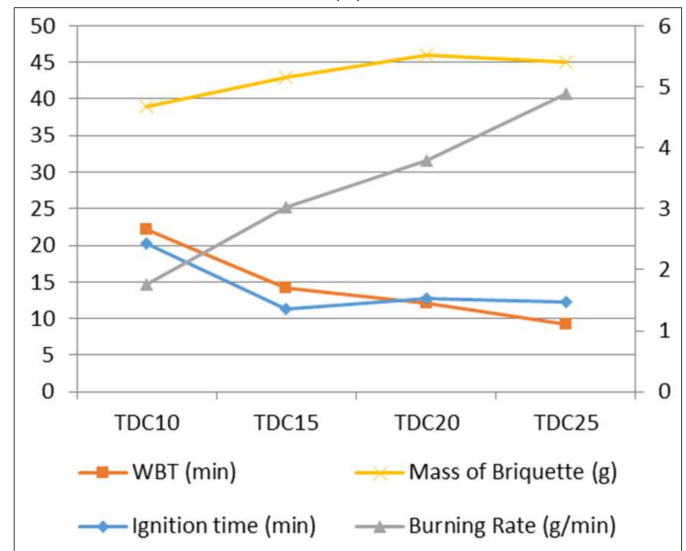

(b)

Figure 6. Thermal characteristics of (a) sun-dried and (b) torrefied carrot briquettes.

\section{Discussion}

The current management of solid waste at D-line fruit and vegetable market, Port Harcourt, Nigeria, conformed to the manner described by Binafeigha and Enwin [31] for Port Harcourt Metropolis. According to the authors, there were no measures in place to ensure the orderly execution of the basic principles of waste management. The waste-management strategies employed at the market included storage, collection and outright disposal at dumpsites.

Cabbage leaves were the most abundant vegetable waste material at the market. The relatively high abundance of this material could be attributed to the large microbial population on the outer leaves of the vegetable leading to spoilage [32]. This part of the vegetable is usually shredded, often in order to make the cabbage look attractive to buyers, as is also described by Ngu and Ledin [33]. Carrot leaves were also observed to be relatively abundant. Apart from the high abundance of cabbage and carrot leaves, their higher heating values of $126 \mathrm{~kJ} / 100 \mathrm{~g}$ and $322 \mathrm{~kJ} / 100 \mathrm{~g}$ respectively [28] also influenced their being chosen as feedstock for the briquetting process. The ash content of the selected residues $(0.81 \%$ and $1.2 \%$ for cabbage and carrot leaves, respectively) was also within the value of less than $4 \%$ recommended by Grover and Mishra [34].

The enhanced compactness and shape of the briquettes formed from torrefied materials compared to those formed from sun-dried and fermented materials was in line with the findings of Koppejan et al. [35]. Torrefaction helps to develop a uniform feedstock which improves binding during pelletization [13] and degrades lignin, which plays an important role in the internal binding of pellets [35]. Sun-dried carrot briquettes became more compact after fermentation. This may be attributed to the low levels of lignin $(1.78 \mathrm{~g} / 100 \mathrm{~g})$ and ash $(1.2 \mathrm{~g} / 100 \mathrm{~g})$ contained in the carrot leaves $[30,36]$. The reduced compactness of the briquettes with increased proportion of paper could 
be due to the relatively larger particle sizes of the paper, which engendered greater pore spaces [37]. Water from these pores was removed and created voids along the structure of the briquettes, which led to cracks [26].

The moisture content of the cabbage and carrot leaves $(84.9 \%$ and $48.5 \%)$ was lower than the $90.3 \%$ and $86.5 \%$ respectively reported by Islam et al. [30]. The moisture content of the briquettes ranged from $3.03 \%$ to $8.47 \%$. This range is slightly lower than the ranges of $5.4-13.3 \%$, wet basis, reported by Olorunnisola [7] for waste paper and coconut admixture. The lower moisture levels of the briquettes are an advantage in the sense that energy will not be utilized to exhume much moisture during combustion. Also, a damp fuel will lead to the excessive emission of fumes and a risk of explosion [25]. The lower moisture content of the torrefied briquettes compared to the sun-dried ones could be explained by the removal of free and chemically bonded moisture resident in the residues with increasing temperature [38]. The lower moisture content of the sun-dried carrot briquettes (3.53-6.13\%) compared to the sun-dried cabbage briquettes (4.61-8.47\%) agrees with the finding of Onukak et al. [25] and may be a result of the levels of moisture in the waste materials. Carrot residues had lower moisture (48.5\%) than cabbage residues (84.9\%).

Briquettes produced with the torrefied carrot waste were denser $\left(0.86 \mathrm{~g} / \mathrm{cm}^{3}-0.90 \mathrm{~g} / \mathrm{cm}^{3}\right)$ than those of sun-dried carrot waste $\left(0.79 \mathrm{~g} / \mathrm{cm}^{3}-0.90 \mathrm{~g} / \mathrm{cm}^{3}\right)$ with few exceptions. This could be attributed to an increase in lignin concentration caused by the pre-heating treatment, thereby improving the binding ability of the biomass and, consequently, enhancing the density [38,39]. Several researchers have found that density values are greatly influenced by a material's moisture content, particle size, the process pressure, and temperature [40,41]. A closer look at the densities of the 20:80 and 25:75 ratios of all the briquette types indicates that the briquettes made from sun-dried carrot have greater densities than those made from sun-dried cabbage, and this could be linked to the higher moisture content and particle sizes of the cabbage residues [13]. The briquettes produced in the study were denser $\left(0.79 \mathrm{~g} / \mathrm{cm}^{3}-0.96 \mathrm{~g} / \mathrm{cm}^{3}\right)$ than those reported by Omoniyi and Igbo [42] within the range of $491.46 \mathrm{~kg} / \mathrm{m}^{3}-623.18 \mathrm{~kg} / \mathrm{m}^{3}$ for rice-husk briquettes using different binders. The degree of compaction achieved for all the briquette types ranged between $343-436 \%$. These values were found to be higher than the $231 \%, 203 \%, 202 \%$ and $219 \%$ reported by Srivastava et al. [17] for cauliflower + cabbage leaves, coriander stalk + leaves, field beans and green bean pods, respectively. The high percentage increase in density from the original bulk density was because the particle sizes of the cabbage and carrot residues were reduced to the point of achieving higher compaction [14].

The relatively lower emissions observed for the briquettes made from torrefied residues could be attributed to the removal of most of the smoke-producing compounds by the pre-heat treatment [13]. The briquettes made from sun-dried cabbage residues had the shortest ignition time of all the briquette types because of their larger particle sizes [25]. The larger particle sizes offered more pronounced pore spaces for the easy percolation of oxygen and the outflow of combustion products during combustion [25,37]. The increase in the time taken to ignite this particular briquette type (Figure 5a) with an increase in the percentage of paper could be due to the increase in the concentration of biomass in those briquette types [16]. Conversely, the time taken to ignite briquettes made from sun-dried and torrefied carrot decreased with the increase in the percentage of paper used as binder (Figure $6 a, b)$. This could be attributed to the reduced compaction, hence more porosity with the increase in percentage of waste paper. This porosity could have led to an inflow of oxygen and an outflow of combustion products [43].

For both the sun-dried and torrefied carrot and cabbage briquettes, boiling time was observed to decrease with an increase in the percentage of the paper binder. Ucuncu and Vesilind [44] reported that the white office paper used in this study had a heating value of $6234 \mathrm{Btu} / \mathrm{lb}(1450 \mathrm{~kJ} / 100 \mathrm{~g})$. This value is higher than those of carrot and cabbage leaves and could have resulted in the reduced boiling time observed with the increase in the percentage of paper from $10 \%$ to $25 \%$. This is in conformity with the findings of Oyelaran et al. [43] on groundnut shell briquettes with a paper binder. Generally, all the briquettes made from torrefied residues boiled water faster than those 
made from sun-dried residues. This could be due to the increased calorific value which results from the torrefaction process $[38,45]$. Comparing the boiling time of carrot briquettes to that of cabbage briquettes revealed that the carrot briquettes boiled water faster than the cabbage briquettes with few exceptions. This could be attributed to the higher calorific value of carrot leaves $(322 \mathrm{~kJ} / 100 \mathrm{~g})$ than cabbage $(126 \mathrm{~kJ} / 100 \mathrm{~g})[28,43]$. The higher boiling time recorded in 20:80 paper:sun-dried carrot briquettes, 25:75 paper:sun-dried carrot briquettes and 10:90 paper:torrefied carrot briquettes than their cabbage counterparts may be due to their lower burning rates of $3.24 \mathrm{~g} / \mathrm{min}, 3.40 \mathrm{~g} / \mathrm{min}$, and $1.75 \mathrm{~g} / \mathrm{min}$, respectively $[27,43]$.

\section{Conclusions}

This study revealed that solid waste management at the D-line market, Port Harcourt, is poor in terms of storage, inconsistent collection and disposal in dumpsites in tandem with the practices across Port Harcourt itself. It also found that the carrot and cabbage waste from the D-line fruit/vegetable market can be readily converted to good quality biomass briquettes with low proportions of waste paper as a binding agent. While the cabbage leaves could be briquetted right after sun-drying for a period of 10 days, the carrot leaves needed to be fermented for relevant compaction to be achieved. Both carrot and cabbage leaves could be subjected to torrefaction in order to increase the heating values, reduce their moisture content and drive off smoke-producing compounds as well as other volatile matter, resulting in higher-quality and better-burning briquettes. The briquettes that were produced had low moisture content within an acceptable range of $3.03-8.47 \%$. The briquettes had high densities within the range of $0.79 \mathrm{~g} / \mathrm{cm}^{3}-0.96 \mathrm{~g} / \mathrm{cm}^{3}$ as compared to $491.46 \mathrm{~kg} / \mathrm{m}^{3}-623.18 \mathrm{~kg} / \mathrm{m}^{3}$ for rice-husk briquettes. Also, the briquettes produced had relatively high ignitability (0.32-4.12 $\mathrm{min})$, fair cooking efficiency judging from the duration each took to boil water (9.21-32.32 min), and burning ratesthat can suit various purposes $(1.75-4.86 \mathrm{~min})$.

Acknowledgments: This paper was extracted from the Master's thesis submitted to the Pan-African University Life and Earth Sciences Institute, University of Ibadan, Nigeria. The research was funded by the African Union Commission. The authors express their sincere gratitude to the Department of Wood Products Engineering, University of Ibadan, for providing the materials and facility for the research, and Enoch Bessah and Davison Kafuli, who edited the manuscript.

Author Contributions: Author O.M.A. carried out the survey, experiments, data analysis and prepared the initial and final drafts of the manuscript. Author A.O.O. conceived the study, supervised the experiments and edited the research report as well as the manuscript drafts. Both authors contributed immensely to the reported study and approved of its publication.

Conflicts of Interest: The authors declare no conflict of interest.

\section{References}

1. United Nations Environment Programme. Solid Waste Management; UNEP International Environmental Technology Centre in Coordination with CalRecovery Incorporated: Nairobi, Kenya, 2005.

2. Obi, O.F.; Adebayo, B.S.; Aneke, N.N. Biomass briquetting and rural development in Nigeria. Int. J. Sci. Environ. Technol. 2014, 3, 1043-1052.

3. Jekayinfa, S.O.; Scholz, V. Potential availability of energetically usable crop residues in Nigeria. Energy Source Part A 2009, 33, 687-697. [CrossRef]

4. Oladeji, J.T. Theoretical aspects of biomass briquetting: A review study. J. Energy Technol. Policy 2015, 5, 72-81.

5. Adegbulugbe, A.O. Energy-environment issues in Nigeria. Int. J. Glob. Energy Issues 1994, 6, 7-18.

6. National Energy Policy. The Presidency Energy Commission of Nigeria. 2003. Available online: http://www.en ergy.gov.ng/index.php?option=com_docman\&task=cat_view\&gid=34\&Itemid=49 (accessed on 9 October 2016).

7. Olorunnisola, A. Production of fuel briquettes from waste paper and coconut husk admixtures. Int. Comm. Agric. Eng. 2007, 9, 1-11.

8. Oladeji, J.T. Agricultural and forestry wastes and opportunities for their use as an energy sources in Nigeria: An overview. World Rural Obs. 2011, 3, 107-112. 
9. Li, M.; Luo, N.; Lu, Y. Biomass energy technological paradigm (BETP): Trends in this sector. Sustainability 2017, 9, 567. [CrossRef]

10. Veringa, H.J. Advanced Techniques for Generation of Energy from Biomass and Waste. ECN Biomass: 2009. Available online: https://www.ecn.nl/fileadmin/ecn/units/bio/Overig/pdf/Biomassa_voordelen.pdf (accessed on 20 March 2018).

11. Tungal, R.; Shende, R. Catalytic subcritical hydropyrolysis of waste biomass into gasoline range hydrocarbons. NSTI-Nanotech 2011, 3, 675-678.

12. Qiao, W.; Yan, X.; Ye, J.; Sun, Y.; Wang, W.; Zhang, Z. Evaluation of biogas production from different biomass wastes with/without hydrothermal pretreatment. Renew. Energy 2011, 36, 3313-3318. [CrossRef]

13. Tumuluru, J.S.; Wright, C.T.; Hess, J.R.; Kenney, K.L. A review of biomass densification systems to develop uniform feedstock commodities for bioenergy application. Biofuel Bioprod. Biorefin. 2011, 5, 683-707. [CrossRef]

14. Kaliyan, N.; Morey, R.V. Factors affecting strength and durability of densified products. In Proceedings of the ASABE (American Society of Agricultural and Biological Engineers) Annual International Meeting, Portland, OR, USA, 9-12 July 2006.

15. Omari, A.M.; Kichonge, B.N.; John, G.R.; Njau, K.N.; Mtui, P.L. Potential of municipal solid waste, as renewable energy source: A case study of Arusha, Tanzia. Int. J. Renew. Energy Technol. Res. 2014, 3, 1-9.

16. Raju, C.A.; Ramya, J.K.; Satya, M.; Praveena, U. Studies on development of fuel briquettes for household and industrial purpose. Int. J. Res. Eng. Technol. 2014, 3, 54-63.

17. Srivastava, N.S.L.; Narnaware, S.L.; Makwana, J.P.; Singh, S.N.; Vahora, S. Investigating the energy use of vegetable market waste by briquetting. Renew. Energy 2014, 68, 270-275. [CrossRef]

18. Bergman, P.C.A. Combined Torrefaction and Pelletization: The TOP Process; ECN Report \# ECN-C-05-073; ECN Biomass: Petten, The Netherlands, 2005.

19. Felfli, F.F.; Luengo, C.A.; Suarez, J.A.; Beaton, P.A. Wood briquette torrefaction. Energy Sustain. Dev. 2005, 9, 19-22. [CrossRef]

20. Ikebude, C.F. Feasibility study on solid waste management in Port Harcourt Metropolis: Causes, effect and possible solutions. Niger. J. Technol. 2017, 36, 276-281.

21. Igwe, C.; Isirimah, N.O.; Teme, S.C. Distribution and characteristics of solid wastes and waste disposal sites in Port Harcourt Municipality Rivers State, Nigeria. J. Environ. Pollut. Health 2002, 1, 51-60.

22. Ayotamuno, J.M.; Gobo, A.E. Municipal solid waste management in Port Harcourt, Nigeria: Obstacles and prospects. Manag. Environ. Qual. Int. J. 2004, 4, 389-398. [CrossRef]

23. Igoni, A.H.; Abowel, M.F.N.; Ayotamuno, J.M.; Eze, C.L. Effect of total solids concentration of municipal solid waste in anaerobic batch digestion on the biogas produced. J. Food Agric. Environ. 2007, 5, 333-337.

24. Babatunde, B.B.; Vicent-Akpu, I.F.; Woke, G.N.; Atarhinyo, E.; Aharanwa, U.C.; Green, A.F.; Isaac-Joe, O. Comparative analysis of municipal solid waste (MSW) composition in three local government areas in Rivers State, Nigeria. Afr. J. Environ. Sci. Technol. 2013, 7, 874-881.

25. Onukak, I.E.; Mohammed-Dabo, I.A.; Ameh, A.O.; Okoduwa, S.I.R.; Fasanya, O.O. Production and characterization of biomass briquettes from tannery solid waste. Recycling 2017, 2, 17. [CrossRef]

26. Moni, M.N.Z.; Sulaiman, S.A.; Raja, Y.S.; Karunamurthy, K.; Inayat, M.; Bou-Rabee, M.A. Investigation of the relationship between moisture content and density of selected Malaysian biomass. J. Mech. Eng. Sci. 2016, 10, 2112-2126.

27. Onuegbu, T.U.; Ekpunobi, U.E.; Ogbu, I.M.; Ekeoma, M.O.; Obumselu, F.O. Comparative studies of ignition time and water boiling test of coal and biomass briquettes blend. IJRRAS 2011, 7, 153-159.

28. Longvah, T.; Ananthan, R.; Bhaskarachary, K.; Venkaiah, K. Indian Food Composition Tables; Longvah, T., Ed.; National Institute of Nutrition; Indian Council of Medical Research; Department of Health Research; Ministry of Health \& Family Welfare; Government of India: Hyderabad, Telanga, India, 2017.

29. Gopalan, C.; Sastri, R.B.V.; Balasubramanian, S.C. Nutritive Value of Indian Foods; National Institute of Nutrition, Indian Council of Medical Research (ICMR): Hyderabad, India, 1989.

30. Islam, R.M.; Paul, D.K.; Shaba, R.K. Nutritional importance of some leafy vegetables available in Bangladesh. Pak. J. Biol. Sci. 2004, 7, 1380-1384.

31. Binafeigha, T.R.; Enwin, A. The state of solid waste management in Port Harcourt City, Nigeria. Am. J. Civ. Eng. Archit. 2017, 5, 160-166. 
32. King, D.J.A.; Michener, D.H.; Bayne, H.G.; Mihara, K.L. Microbial studies of shelf life of cabbage and coleslaw. Appl. Environ. Microbiol. 1976, 31, 404-407. [PubMed]

33. Ngu, N.T.; Ledin, I. Effects of feeding wastes from Brassica species on growth of goats and pesticide/insecticide residues in goat meat. J. Anim. Sci. 2005, 18, 197-202. [CrossRef]

34. Grover, P.D.; Mishra, S.K. Biomass Briquetting: Technology and Practices; The FAO Regional Wood Energy Development Programme in Asia: Banglok, Thailand, 1996; pp. 1-43.

35. Koppejan, J.; Sokhansanj, S.; Melin, S.; Madrali, S. Status Overview of Torrefaction Technologies. IEA Bioenergy Task 32 Report: Final Report. 2012. Available online: http://www.ieabcc.nl/publicat ions/IEA_Bioenergy_T32_Torrefaction_review.pdf (accessed on 28 December 2017).

36. Bikash, B.; Bhowmik, R.; Madhurjya, S. Challenges of wet briquetting from locally available biomass. Int. J. Mod. Eng. Res. 2013, 3, 1707-1711.

37. Davies, R.M.; Abolude, D.S. Ignition and burning rate of water hyacinth briquettes. J. Sci. Res. Rep. 2013, 2, 111-120. [CrossRef] [PubMed]

38. Saeed, A.M.; Ahmad, S.W.; Kazmi, M.; Muhammad, M.; Feroze, N. Impact of torrefaction technique on the moisture contents, bulk density and calorific value of briquetted biomass. Pol. J. Chem. Technol. 2015, 17, 23-28. [CrossRef]

39. Gravalos, I.; Kateris, D.; Xyradakis, P.; Gialamas, T.; Loutridis, S.; Augousti, A.; Georgiades, A.; Tsiropoulos, Z. A study on calorific energy values of biomass residue pellets for heating purpose. In Proceedings of the Forest Engineering: Meeting the Needs of the Society and the Environment, Padova, Italy, 11-14 July 2010.

40. Rhen, C.; Gref, R.; Sjöström, M.; Wästerlund, I. Effects of raw material moisture content: Densification pressure and temperature on some properties of Norway spruce pellets. Fuel Process. Technol. 2005, 87, 11-16. [CrossRef]

41. Mani, S.; Tabil, L.G.; Sokhansanj, S. Specific energy requirements for compacting corn stover. Bioresour Technol. 2006, 97, 1420-1426. [CrossRef] [PubMed]

42. Omoniyi, T.E.; Igbo, P.K. Physico-mechanical characteristics of rice husk briquettes using different binders. Agric. Eng. Int. CIGR J. 2016, 18, 70-81.

43. Oyelaran, O.A.; Bolaji, B.O.; Waheed, M.A.; Adekunle, M.F. Performance evaluation of the effect of waste paper on groundnut shell briquette. Int. J. Renew. Energy Dev. 2015, 4, 95-101. [CrossRef]

44. Ucuncu, A.U.; Vesilind, P.A. Energy Recovery from Mixed Waste Paper. Waste Manag. Res. 1993, 11, 507-513. [CrossRef]

45. Dhital, H.C.; Bajaracharya, T.R. A research on torrefaction and briquetting of biomass in Nepal. In Proceedings of the IOE Graduate Conference, Tribhuvan University, Kirtipur, Nepal, 29 November 2013; Volume 1, pp. $103-107$. 